\title{
UN ERRORE SIGNIFICATIVO NELLA TRADIZIONE DI GENESI 47:5-6
}

ALESSANDRO CATASTINI

Università di Pisa

Dopo aver visto nella terra di Goshen il padre e i fratelli, Giuseppe ne informa dapprima il faraone e, successivamente, conduce al suo cospetto cinque di essi, i quali richiedono l'autorizzazione per soggiornare nella terra stessa, autorizzazione che il faraone concederà. Questi fatti sono narrati in $G n$ 47:1-5, versetti che richiamano l'attenzione per le discrepanze esistenti tra TM e la tradizione antica dei LXX in relazione ai 5-6.

Così l'ebraico del Leningradensis (testo BHS):

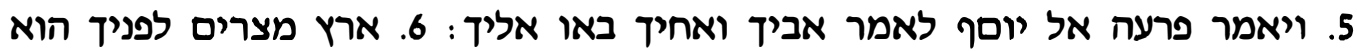

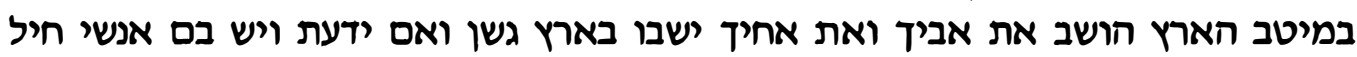

ושמתם שרי מקנה על אשר לי.

Così il greco ':

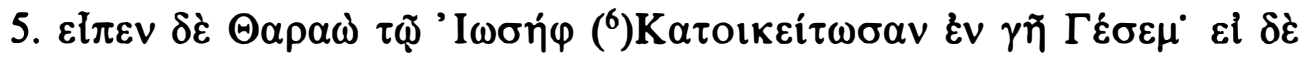

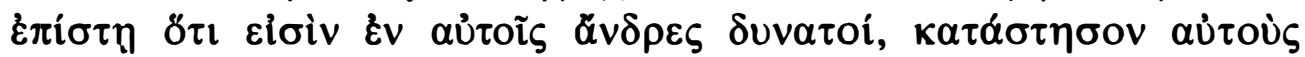

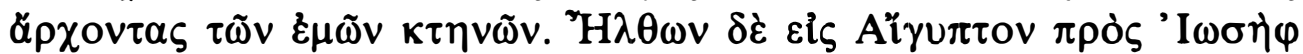

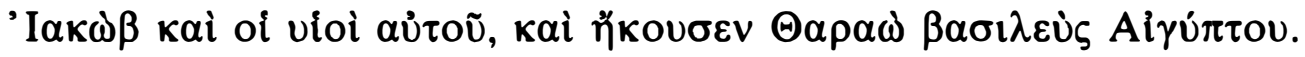

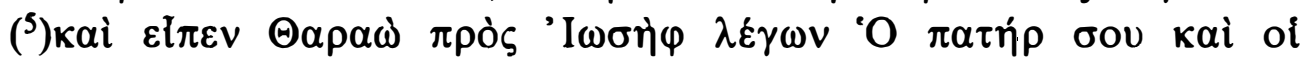

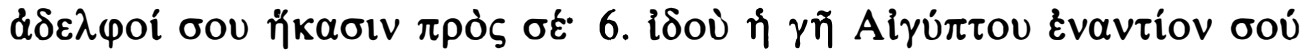

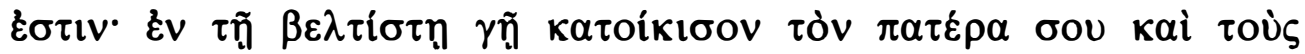

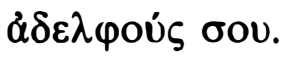

La logica della narrazione è esposta compiutamente nei LXX, mentre nel TM è confusa e non consequenziale sotto due aspetti: da

\footnotetext{
${ }^{1}$ Mi baso sull'edizione di J. W. Wevers, Septuaginta. Vetus Testamentum Graecum Auctoritate Academiae Scientiarum Gottingensis editum, vol. I: Genesis, Göttingen 1974.
} 
un lato, in relazione alla precisa istanza di Giuseppe sul soggiorno nella terra di Goshen; dall'altro, è del tutto fuori luogo che il faraone informi Giuseppe che i suoi parenti sono arrivati, quando proprio quest'ultimo gli ha appena detto la stessa cosa al versetto $1^{2}$.

Il testo ebraico dei vv. 5-6 si presenta senz'altro disturbato, quindi, e non adiaforamente alternativo ai LXX: per questo motivo ritengo non si possa pensare che questi ultimi attestino una pura e semplice espansione targumica estranea a Vorlagen ebraiche ${ }^{3}$. D'altra parte, una retroversione dei LXX ci visualizza immediatamente la possibilità di un errore meccanico dal quale può in qualche modo dipendere la tradizione di TM. Valendomi anche dei suggerimenti dell'apparato della BHS, azzardo quindi un'ipotetica Vorlage, sottolineando quelle parti che non hanno corrispondenza in TM ${ }^{4}$ :

${ }^{2}$ Alcune traduzioni italiane cercano di ovviare a questa impasse traducendo "Tuo padre e i tuoi fratelli sono dunque venuti da te" (cfr. La Sacra Bibbia, a cura e sotto la direzione di Mons. S. Garofalo, Torino - Roma 1974'), ma i problemi di congruenza testuale non si cancellano. Per comodità del lettore, fornisco una traduzione dei due testi: TM “5. Il faraone disse a Giuseppe: tuo padre e i tuoi fratelli sono venuti da te. 6. La terra d'Egitto è davanti a te. Fai abitare nella parte migliore del paese tuo padre e $i$ tuoi fratelli. Abitino pure nella terra di Goshen e se vedi che vi sono fra essi degli uomini di valore, ponili a (sorvegliare) i miei averi come sovrintendenti al bestiame. E vennero in Egitto, da Giuseppe, Giacobbe e i suoi figli. E udi (la cosa) il faraone, re d'Egitto. Il faraone disse a Giuseppe: tuo padre e $\mathrm{i}$ tuoi fratelli sono venuti da te. 6. Ecco, la terra d'Egitto è davanti a te. Fai abitare nella parte migliore del paese tuo padre e i tuoi fratelli". È appena il caso di osservare che in favore del TM non è applicabile neanche il criterio della lectio difficilior; ci si ricordi di questa esortazione: “...̀̀ sempre raccomandabile, prima di prendere una decisione sulla base del criterio della lectio difficilior, fare la controprova chiedendosi: "cosa è qui veramente plausibile: che la lezione strana, poiché più difficile, s'è corrotta in quella più facile, ovvero che la lezione strana è quella difficile perché è corrotta?'»; cfr. H. FränKel, Testo critico e critica del testo, Firenze $1983^{2}$ [ed. or. Einleitung zur kritischen Ausgabe der Argonautika des Apollonios, Göttingen 1964], p. 37.

${ }^{3}$ La successione degli avvenimenti quale è esposta nei LXX, inoltre, è confortata da un precedente analogo: in 45:16 ss, il faraone apprende che sono giunti i fratelli di Giuseppe e quindi esorta quest'ultimo a far venire tutta la sua famiglia in Egitto. Non sono quindi d'accordo con A. B. EhrLICH, Randglossen zur hebräischen Bibel, I Leipzig 1908, p. 235, che preferisce TM.

${ }^{4}$ Per quanto riguarda la possibile Vorlage del dativo $\tau \tilde{\varphi}$ 'I $\omega \sigma \eta ́ \varphi$, sono plausibili tanto אלanto 4 , anche se dai dati statistici relativi al corpus di Gn 37-50 si rileva una netta predominanza di ויאמר ל- : ויאל אל - Dativo: 38:8,11; 40:12; 41:55; 43:16; 44:15; 48:1,2. Прós: Ø. ויאמר אל Dativo: 37:10,22; 39:8; 40:8,16,18; 41:15,17,25, $38,39,41,44 ; 42: 7,9,12,14,18,28,33,36,37 ; 43: 2,3,11 ; 45: 24 ; 47: 3,5,8,9,23 ; 48: 3,4,9,18,21$; 49:29; 50:19. Прós: 37:26; 43:8; 44:27; 46:30; 48:11. Mantengo inoltre la lezione

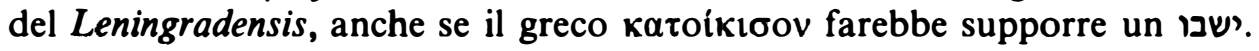




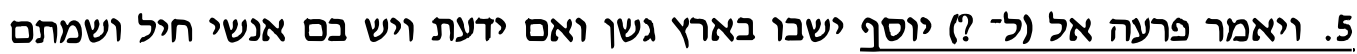

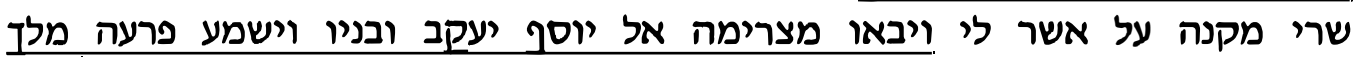

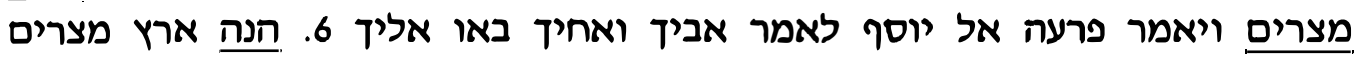
לפניך הוא במיטב הארץ הושב את את אביך ואת אמר אביך ואחיך.

Come si vede, in un testo del genere può verificarsi un saut $d u$ même au même tra i due ויאמר פרעה. Un'obiezione all'eventualità di questa aplografia può però essere data dal fatto che la porzione è ישבו בארץ גשן ואם ידעת ויש בם אנשי חיל ושמתם שרי מקנה על אשר לי presente in TM, ma questa obiezione si regge solamente se si vuol considerare TM come diretta risultante del danno meccanico. Un tipico esempio di come casi del genere siano stati affrontati basandosi sulle teorie letterarie della "critica alta» ci viene fornito J. Skinner, che ipotizza il sovrapporsi, nella tradizione di LXX, delle tradizioni di J e P s: «It will hardly be disputed that the text of LXX is here the original and that P's narrative commences with the additional sentences quoted above [scil. il testo ebraico ricostruito]. The editor of MT felt the doublet to be too glaring; he therefore omitted these two sentences; and then by transposition worked the two accounts into a single scene. A further phase is represented by Hex. Syr., where $5 \mathrm{~b}$ and $6 \mathrm{a}$ are omitted. We have here an instructive example of the complex process by which the sources were gradually worked into a smooth narrative, and one which deserves the attention of those writers who ridicule the minute and intricate operations which the critical theory finds it necessary to attribute to the redactors".

Sulla recenziorità della tradizione di TM si è espresso, più di recente, anche Speiser ${ }^{6}$, il quale però chiama giustamente in causa gli accidenti meccanici della trasmissione: "The fact that LXX is selfexplanatory indicates that the disturbance in MT is relatively late. The authenticity of the Greek version should be clear from the context; note especially the logical transition from $4 \mathrm{~b}$ (Please, may we stay in Goshen) to $6 \mathrm{~b}$ (Yes, they may stay in Goshen). Above all, the sentences which LXX supplies will readily account for the difficulties in the received text: the added part ends with "Pharao turned (spoke) to Joseph, saying", the identical clause that both MT and LXX read in

\footnotetext{
5 J. Skinner, A Critical and Exegetical Commentary on Genesis, Edinburgh $1930^{2}$, p. 498.

${ }^{6}$ E. A. SpEISER, Genesis. Introduction, Translation, and Notes, Garden City (N.Y.) 1981, pp. 351-352.
} 
5a. Such endings (a feature known as homoioteleuton) often cause copyists to confuse the first occurrence with the second, and hence skip the intervening part; for a parade example, cf. I Sam XIV 41, where LXX comes again to be rescue in a context of unusual importance. The upshot in the present instance has been the loss of a sentence and the consequent dislocation of 5b-6a».

Caratteristica di questo metodo d'indagine è la ricerca del «testo originale" valutando caso per caso quando si presentano delle varianti, senza in definitiva arrivare a una valutazione d'insieme delle diverse tradizioni manoscritte o, meglio, evitando di definire in un qualche modo la relazione stemmatica esistente, sia pure in una recensione che risulti aperta?.

E utile ricordarci, a questo proposito, del concetto di «innovazione», che può essere di per sé stemmaticamente significativa purché non poligenetica. In altre parole, parte della tradizione potrebbe rivelarsi portatore di lezione che, in forma linguisticamente erronea o meno, modifichi la forma dell'originale; se questa lezione non ha le caratteristiche per verificarsi indipendentemente in più testimoni, assume carattere genealogicamente significativo per il collegamento o la separazione di questi ultimi ${ }^{8}$.

Ora, un caso come quello in questione vede senz'altro il TM nella posizione di portatore di innovazione, anzi di innovazioni. Da un lato quella del saut, tipicamente poligenetica, ininfluente al fine di collegare con sicurezza tra loro due o più testimoni manoscritti che la attestino. D'altro lato, se il TM ha chiaramente subito l'aplografia meccanica, questo presenta anche un testo ulteriormente evoluto che, se pure non restaura la congruente successione degli avvenimenti, si presenta come un tentativo di porre maldestramente riparo al guasto. Il testo ebraico ricostruito sulla base dei LXX, invece, funziona egregiamente nel contesto e, accogliendo le opinioni suesposte, possiamo senz'altro senz'altro considerarlo come l'originale. Il conciero di TM è stato introdotto in base alla tradizione genuina, ma con una integrazione solo parziale e non al posto giusto. Questo fenomeno è tutt'altro che sconosciuto ai filologi: un caso classico è quello dell'inserimento nel

${ }^{7}$ Nessuna posizione in merito viene presa nel recente studio di H. SCHWEIZER, Die Josephsgeschichte. Konstituierung des Textes. I: Argumentation, II: Textband, Tübingen 1992.

${ }^{8}$ Mi permetto di rimandare, per un'esposizione di questo concetto con applicazione alla filologia veterotestamentaria, al mio A. CATASTINI, «Da Qumran al Testo Masoretico dell'Antico Testamento: spunti metodologici per la valutazione delle varianti", $R Q 15$ (1991) 303-313. 
testo, in fase di copiatura, di correzioni notate in margine, ove non sempre accade che il testo sia inserito correttamente 9 . Tuttavia, se il fenomeno è conosciuto almeno quanto il saut, non è altrettanto ininfluente dal punto di vista stemmatico. In altre parole, non è facilmente poligenetico e, comunque, penso si possa affermare che non lo è per il caso in questione. Questa conclusione non è indifferente: $\mathrm{i}$ LXX ci attestano sostanzialmente l'originale, del quale si è proposto una ricostruzione nella forma ebraica, mentre i testimoni che sono portatori dell'errore significativo di $G n$ 47:5-6 sono congiunti nel provenire dal medesimo subarchetipo corrotto e, allo stesso tempo, separati dalla tradizione risalente al testo originale.

Per quel che si può vedere, la lezione corrotta di TM pare non essere contrastata da quella dei LXX né nella tradizione ebraica antica ${ }^{10}$ e medievale ", né in quelle di versioni verificabili su edizioni più $\mathrm{o}$ meno critiche: Peshitta ${ }^{12}$, Vulgata ${ }^{13}$, targumîm Onquelos ${ }^{14} \mathrm{e}$ palestinesi 15 .

${ }^{9}$ Cfr. la casistica raccolta in R. Renehan, Greek Textual Criticism. A Reader, Cambridge (Mass.) 1969, in particolare le pp. 35-37, relative a due esempi in Euripide. Per il testo biblico, cfr. il caso messo in luce da S. TALMON, "Aspects of the Textual Transmission of the Bible in the Light of Qumran Manuscripts», Textus 4 (1964) 93$132,118$.

${ }^{10}$ I versetti non sono attestati a Qumran, almeno verificando quanto in proposito è stato pubblicato o ancora si trova sotto forma di tesi di dottorato: J. R. DAviLA, Unpublished Pentateuchal Manuscripts from Cave IV, Qumran 4QGenEx $x^{\mathrm{a}}$, Gen ${ }^{\mathrm{b}-\mathrm{h}}$, Gen ${ }^{\mathrm{j}-\mathrm{k}}$, Diss. Harvard, Cambridge (Mass.) 1988: colgo l'occasione per ringraziare Davila per avermi permesso di visionare e citare il suo lavoro.

1 Nelle collazioni delle tradizioni palestinese e babilonese, per adesso, il passo non risulta attestato: cfr. B. CHIESA, L'Antico Testamento ebraico secondo la tradizione 'palestinese', Torino 1978, e G. MiletTo, L'Antico Testamento ebraico nella tradizione babilonese. I frammenti della Genizah, Torino 1992. Per la tradizione tiberiense, tenendo presenti i limiti che pongono, occorre ancora rifarsi alle collazioni di B. KenNiCOTT, Vetus Testamentum hebraicum cum variis lectionibus, I, Oxonii 1776, e G. B. DE Rossi, Variae lectiones Veteris Testamenti, I, Parmae 1784. Anche la tradizione samaritana si allinea con la lezione di TM; cfr. L. F. Girón Blanc, Pentateuco hebreo-samaritano: Génesis. Edición critica sobra la base de manuscritos inéditos, Madrid 1976.

12 The Peshițta Institute (edd.), The Old Testament in Syriac according to the Peshitta Version. I/1: Genesis - Exodus, Leiden 1977.

${ }^{13}$ H. QUenTIN (ed.), Biblia Sacra iuxta latinam vulgatam versionem. Librum Genesis, Romae 1926.

14 A. Sperber (ed.), The Bible in Aramaic. I: The Pentateuch according to Targum Onqelos, Leiden 1959.

15 AA. VV. (sotto la direzione di A. Dfez MACho), Biblia Polyglotta Matritensia. Series IV. Targum Palestinense in Pentateuchum. Additur Targum Pseudojonatan eiusque hispanica versio. L. 1: Genesis, Matriti 1988. 
La tradizione così scandagliata nel caso che abbiamo esaminato ci consente di proporre lo stemma che segue:

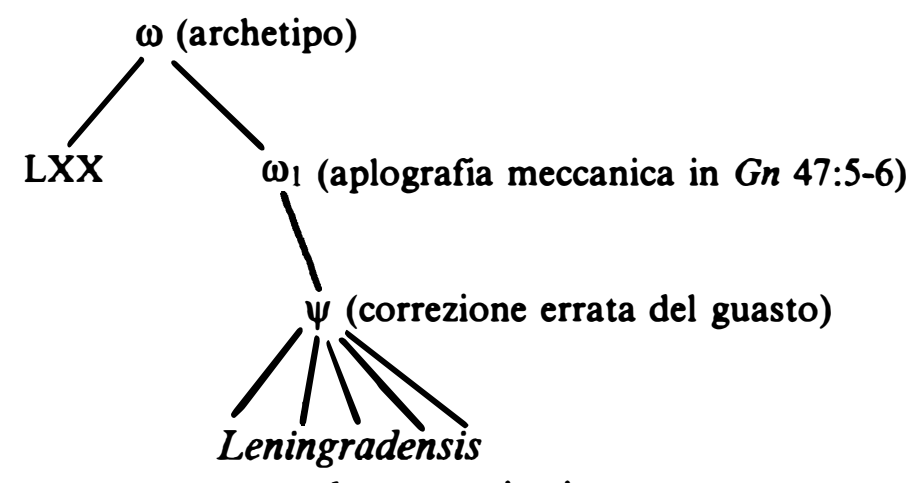

mss. ebr. e versioni .

\section{RESUMEN}

Este artículo examina el texto de Génesis 47,5-6. Respecto al TM, LXX presenta un texto más extenso que, en su forma originaria hebrea (bien reconstruible), muestra las características por un error mecánico banal poligenético (homoioteleuton) que ha tenido lugar en un cierto momento de la transmisión. La forma final del TM se revela como la resultante de un intento de subsanar el error; sin embargo, tal tentativa es torpe y viene a determinar un error esta vez no poligenético, significativo desde el punto de vista de la filiación de los testimonios: LXX atestigua el original, mientras que el texto de la tradición del versículo constituye una ramificación independiente que arranca del subarquetipo $(\Psi)$, que a su vez se remonta al error significativo.

\section{SUMMARY}

In this article the text of Genesis 47:5-6 is examined. In relation to the MT, the LXX presents a longer text which, in its earliest hebrew form (which can well be reconstructed), shows the characteristics of a banal mechanical polygenetic error (saut du même au même) taking place at a particular moment of the transmission. The final form of the MT is shown as the result of an attempt of correcting the error; nevertheless, such attempt is rough and comes to determine an error this time nonpolygenetic, meaningful from the point of view of the genealogical relationships among the witnesses: the LXX testifies the original while the text of the tradition of the verse constitutes an independent branch deriving from the subarchetype ( $\Psi$ ) which bears the significant error. 